\title{
Development of Student Activity Sheets Based on Local Wisdom to Improve Critical Thinking Skills of Science 4th Grade Elementary School
}

\author{
Novita Anggraeni \\ Postgraduate Program of Elementary Education Department \\ State University of Surabaya \\ Surabaya-East Java -Indonesia
}

\begin{abstract}
This study aims to produce and describe the validity, practicality, and effectiveness of Student Activity Sheets based on the local wisdom of Surabayaspecific Batik that can improve critical thinking skills in science subjects 6th grade Elementary School. This research is a development research that refers to the Four D (4D) development model. Student Activity Sheet based Surabaya batik local wisdom validated by experts, then tested on 20 fourth grade students of Mulyorejo I / 237 Elementary school Surabaya. The results showed that the Student Activity Sheet that was developed was very valid with a percentage of $92.25 \%$, the Student Activity Sheet that was developed practically based on student activities relevant to learning with a percentage of $92.71 \%$, and the Student Activity Sheet that was developed effectively based on the results Student's critical thinking test which showed that all students completed with an $\mathrm{N}$-gain of 0.751 in the high category. It can be concluded that the Student Activity Sheet based Surabaya batik local wisdom deserves to improve the critical thinking skills of elementary students.
\end{abstract}

Keywords:- Student Activity Sheet, Local Wisdom, Critical Thinking.

\section{INTRODUCTION}

Saeed S.J and Rousta. S.N (2013) which explains that thinking skills are increasingly emphasized in education because of globalization which requires workers to be more productive. Critical thinking becomes a skill needed by students to be able to deal with various changing situations in the era of globalization that continues to develop.

According to Norris (1989) students need critical thinking skills so that students are accustomed to solving the problems they face. Teaching critical thinking is important for an individual who is learning. If students' critical thinking skills do not develop, they will inhibit their ability to solve the problems they face.

One way to practice critical thinking skills is through science education. Carin and Sund (1989) say that science or science is science that is systematic, generally applies and is a collection of data and observations and experiments. Based on this, science is very suitable to be used as a means

\author{
Suryanti, Widowati Budijastuti \\ Postgraduate Program of Elementary Education Department \\ State University of Surabaya \\ Surabaya-East Java -Indonesia
}

to foster and strengthen attitudes, knowledge, and skills periodically for students at every level.

Information conveyed to students through learning in order to be meaningful and enduring in students needs to be linked to the real world. According to Susanto (2013), children's mental development starts from the concrete thinking stage because the child's world is the real world.

Children always see objects that are nearby as something whole. Therefore, learning should be done from the immediate environment of students, namely oneself and then developing in the family environment, and the wider environment, namely school. Gasong (2018) argues that contextual learning is learning that connects learning with real situations around students. Students will connect the concepts they already have and apply them to the problems they face everyday.

The observations of researchers in the field indicate that students' critical thinking skills are still low. This is indicated by the answers of students when working on the student activity sheet contained in the student book. Students have not been able to observe and write down observations correctly. Students tend to be confused in processing data and conclude the observations they do.

The low critical thinking skills of these students are not without cause. Based on the results of observations and interviews of researchers with the 4th grade teacher, information was obtained that students rarely did learning using student activity sheets. Students are not accustomed to learning which involves students' activeness in finding out and building their knowledge. Teachers also very rarely use student activity sheets contained in student books with the reason to take up a lot of time and students are not conducive if doing group activities.

Data obtained by researchers in the field shows that from the planning used teachers still use standard planning obtained from the internet or from student books. Though it is known that the plan is very general in nature and not necessarily in accordance with the conditions and needs of students. The indicators contained in the planning have not yet reached the higher order thinking skills, and are only short term. In the learning step is still dominated by the teacher, so students do not participate actively in learning. This is supported by interviews with $4^{\text {th }}$ grade teachers about 
science learning. The teacher tells that when learning science students are often passive when learning. In addition students also have difficulty analyzing problems in science. The teacher reveals that students always stick to the explanations given by the teacher. Learning is more dominated by giving material and exercises and worksheets from student books. This results in students being less able to develop their skills in solving problems and applying the concepts they learn in school in everyday life. Students only listen to the material in the direction of the teacher so that they are not used to expressing their ideas. This is what causes students to be passive when learning and students' critical thinking skills are low. This is what causes the need to be done or made teaching material that is able to make students active in learning so as to improve thinking skills from simple to more complex.

In the student book the students actually have completed with student activity sheets, but they do not qualify as good student activity sheets. The student activity sheet contained in the student book is not equipped with indicators, learning objectives and work instructions. Most student activity sheets in the student book go directly to the tools and materials, step activities and the results of observations / research. Even though clear instructions are needed to work on the student activity sheet so that students are not confused in working on it. In addition there is no formulation of conclusions in the student activity sheet in the student book. In fact, concluding is one of the indicators of critical thinking students must have so that students can understand the core of their learning.

Problems with learning in the classroom, difficulties students understand what they have learned, efforts are needed to stimulate students to think critically, logically, and effectively so that learning that is carried out must be able to practice students' critical thinking skills when learning in class and in solving problems in life everyday like the integration of local wisdom. Students will get used to learning through problems that require critical thinking. The effort to introduce local wisdom in learning is very important in preserving culture.

The teacher's effort to realize the desired learning achievement was formed Student Activity Sheet which can be one way that can be done to help students and facilitate students in learning. Student Activity Sheets that create an effective relationship between teacher and student can increase student activity and will have an impact on increasing learning outcomes.

To explore the ability of students in critical thinking teachers need to apply meaningful learning and learning experiences will always be remembered by students because the learning process is fun. Local wisdom is considered capable of making natural science learning more meaningful and enjoyable. Marfai (2012) said that local wisdom is a reciprocal relationship between humans and the environment and as a result of a long ongoing process of a form of guidelines, views of rules, and unwritten rules found in society.
Each region has its own local wisdom, as well as Surabaya. One of the local wisdoms in Surabaya is Surabaya Batik. Based on research conducted by Eni Kurniawati (2015), Surabaya batik has a distinctive style that is different from other regions.

Based on the description above, the researcher is motivated to develop a valid, practical and effective local Wisdom-based Student Activity Sheet on the science content with the title " Development of Student Activity Sheets Based on Local Wisdom to Improve Critical Thinking Skills of Science $4^{\text {th }}$ Grade Elementary School ". Student Activity Sheet Product is expected to be an alternative for educators as teaching material and can facilitate students to build their own understanding, and improve critical thinking skills.

\section{METHOD}

The research conducted is a research development. In this study, researchers sought to develop student sheets based on local wisdom to improve critical thinking skills. The development model used to develop in this study is the 4D (Four D) development model. The reason for using this model is because this model has clearer steps at each stage of its development. The subjects of this study were 4th grade elementary school students. The research location taken was Mulyorejo I elementary school. The choice of location was taken because of several reasons, namely: 1) the location of the school close to the mangrove tourism area in accordance with the material to be taught, 2) the number of parallel classes in the school is more than 2 classes, 3) the school is very open in accepting innovations in education , 4) the willingness of the school to help the research process.

\section{A. Research Procedure \\ $>$ Defining Phase}

At this stage the researcher determines and defines the needs of learning. Namely needs analysis, student analysis, and task analysis.

\section{$>$ Design Stage}

At this stage the researcher designs a student excitement sheet. This design phase includes the design of student activity sheets based on local wisdom, the design of the use of student activity sheets and expert validation.

\section{$>$ Development Stage}

The development phase is based on a draft that has been prepared. The steps are validation with experts and conducting limited trials.

\section{$>$ Dissemination Stage}

After conducting a limited trial and revision of the instrument, the next stage is the deployment stage. At this stage the researcher disseminates Student Activity Sheets to the teacher. Researchers conducted a second trial in the replication class. The Student Activity Sheet which was revised after the first trial was used as draft three. Draft 3 that has been revised is applied for the second trial, then 
ISSN No:-2456-2165

used as material to prepare the thesis report which is then tested in front of the board of examiners.

\section{B. Data collection technique \\ $>$ Test}

Students are given a pretest to find out how far the students' abilities are before using the Student Activity Sheet. After conducting learning activities using the Student Activity Sheet, students conduct a post-test to find out the improvement in students' critical thinking skills.

\section{Non test}

The author made observations to assess the feasibility of student activity sheets. Practical learning with student activity sheets and learning effectiveness with student activity sheets developed.

\section{Research Instrument}

\section{$>$ Eligibility Student activity sheets}

The instrument for evaluating the validity of Student Activity Sheets is to use a validation sheet to assess the feasibility of Student Activity Sheets, namely the questionnaire as a validation sheet to the expert to determine the assessment of Student Activity Sheets and the questionnaire on a trial to find out how students respond to the weaknesses of Student Activity Sheets.

\section{Practicality Student activity sheet}

To find out the practicality of the Student Worksheet, the researcher used the Observation Observation Sheet, Student Activity Observation Sheet, and Obstacle Observation Sheet During Learning

\section{Effectiveness of Student Activity Sheets}

This critical thinking skill is measured by administering tests in the form of subjective questions related to the material that has been taught. Assessment is done through pretest and posttest before and after learning to find out how far the ability of students after learning is carried out.

\section{Data Analysis Technique}

All data that has been obtained is then analyzed quantitatively and qualitatively. Qualitative data are expert judgments through validation, student responses, and observation sheets. Qualitative data intended here is the result of evaluating critical thinking to assess the effectiveness and feasibility of Student Activity Sheets based on local wisdom.

\section{Feasibility Student Activity Sheet}

The Student Activity Sheet that is developed is reviewed and rated as validator. The final results of the assessment of two validators were averaged. Based on the data obtained, the appropriateness of the device is assessed based on the criteria below:

\begin{tabular}{|c|c|c|}
\hline Interval & Category & Information \\
\hline $\begin{array}{c}1,0 \leq \mathrm{SV} \leq \\
1,5\end{array}$ & Invalid & $\begin{array}{c}\text { Can not be used, requires } \\
\text { consultation }\end{array}$ \\
\hline $\begin{array}{c}1,6<\mathrm{SV}< \\
2,5\end{array}$ & Invalid & $\begin{array}{c}\text { Can be used with many } \\
\text { revisions }\end{array}$ \\
\hline $\begin{array}{c}2,6<\mathrm{SV}< \\
3,5\end{array}$ & Valid & $\begin{array}{c}\text { Can be used with a slight } \\
\text { revision }\end{array}$ \\
\hline $\begin{array}{c}3,6<\mathrm{SV}< \\
4,0\end{array}$ & Very Valid & $\begin{array}{c}\text { Can be used, without } \\
\text { revision }\end{array}$ \\
\hline
\end{tabular}

Table 1:- Criteria for Categorizing the Results of Validation Learning tools (Ratumanan and Laurens, 2006)

Student questionnaire is used to determine student responses to the Student Activity Sheet that was done. The response obtained is processed using the formula:

$P=\frac{f}{N} \times 100 \%$

$\mathrm{P}=$ Presentase

$\mathrm{F}=$ Number of Voters

$\mathrm{N}=$ Total number of students

\begin{tabular}{|c|c|c|c|}
\hline Percentage & Category & Qualification & Explanation \\
\hline $85 \%-100 \%$ & A & Very high & $\begin{array}{c}\text { No Need for } \\
\text { Revision }\end{array}$ \\
\hline $75 \%-84 \%$ & B & high & $\begin{array}{c}\text { No Need for } \\
\text { Revision }\end{array}$ \\
\hline $65 \%-74 \%$ & C & Enough & Revision \\
\hline $55 \%-64 \%$ & D & Less & Revision \\
\hline $0 \%-54 \%$ & E & Very less & Revision \\
\hline
\end{tabular}

Table 2: Criteria for Categorizing Student Questionnaire Assessment Results (Sugiyono, 2012)

\section{Practicality of Student Activity Sheets}

The instrument of implementation of learning in the classroom that has been done by researchers is used to analyze the management of learning that has been done by finding an average score.

$$
P=\frac{\text { average score }}{\text { maximum score }} \times 100 \%
$$

\begin{tabular}{|c|c|}
\hline Criteria & Explanation \\
\hline $85,01 \%-100 \%$ & $\begin{array}{c}\text { Very effective, can be used without } \\
\text { repair }\end{array}$ \\
\hline $70,01 \%-85,00 \%$ & $\begin{array}{c}\text { Quite effective, can be used with a } \\
\text { little improvement }\end{array}$ \\
\hline $50,01 \%-70,00 \%$ & $\begin{array}{c}\text { Less effective, needs major } \\
\text { improvement }\end{array}$ \\
\hline $1,00 \%-50,00 \%$ & Not effective, can not be used \\
\hline
\end{tabular}

Table 3: Criteria for Learning Implementation (Akbar, 2013) 
Student observation sheets can be through observations made by an observer, through the sheet will be obtained data about student activities during learning.

$$
P=\frac{\text { many student activities }}{\text { Total number of activities }} \times 100 \%
$$

\begin{tabular}{|c|c|c|}
\hline Num & Activity Score (\%) & Category \\
\hline 1 & $76-100$ & High \\
\hline 2 & $56-75$ & Enough \\
\hline 3 & $40-55$ & Less \\
\hline 4 & $<40$ & Low \\
\hline
\end{tabular}

Table 4: Criteria for categorizing student activities (Arikunto, 2008)

Obstacles encountered during teaching and learning activities using student activity sheets based on local wisdom that were developed were analyzed through discussion with observers and sought alternative solutions.

\section{Effectiveness of Student Activity Sheets}

This design uses a pretest before treatment to determine the initial state (cognitive) in the sample. After the treatment in the form of the use of student activity sheets based on local wisdom is carried out post-test as a measurement of critical thinking skills in each class to determine the effect of learning through student activity sheets based on local wisdom.

Increased critical thinking skills were analyzed using gain scores between pretest and posttest scores using formulas (Hake, 1999):

$$
g=\frac{\text { Spost }- \text { Spre }}{\text { Skor } \max -\text { Spre }}
$$

Information:

$\mathrm{g}($ gain $)=$ increased level of mastery of concepts

$\mathrm{S}_{\text {post }}=$ final test score

$\mathrm{S}_{\text {pre }} \quad=$ initial test score
High and low normalized gain (n-gain) can be classified in Table 2 as follows.

\begin{tabular}{|c|c|}
\hline Interval & Category \\
\hline $0,7 \leq \mathrm{g}$ & High \\
\hline $0,3 \leq \mathrm{g}<0,7$ & Medium \\
\hline $\mathrm{g}<0,3$ & Low \\
\hline
\end{tabular}

Table 5:- Categorization Criteria for N-Gain (Meltzer, 2002)

The division of $\mathrm{N}$-gain acquisition categories in the form of percent (\%) can be presented in Table 3 as follows.

\begin{tabular}{|c|c|}
\hline Percentage (\%) & Interpretation \\
\hline$<40$ & Ineffective \\
\hline $40-55$ & Less Effective \\
\hline $56-75$ & Effective Enough \\
\hline$>76$ & Effective \\
\hline
\end{tabular}

Table 6:- Categories of N-Gain Effectiveness Interpretation (Hake,R.R, 1999)

\section{RESULT AND DISCUSSION}

This research went through four stages, namely planning, design, development, and dissemination. At the design stage the researcher makes the instrument to be validated by several experts. The results of the validation are a reference for researchers to develop instruments. After the instrument is developed, it is then distributed to be tested on students. This research was conducted at Mulyorejo I / 237 elementary school in Surabaya. The subjects of this study were 20 fourth grade students with details of 10 male students and 10 female students.

\section{A. Feasibility Student Activity Sheet}

This Student Activity Sheet is validated by two experts. This Student Activity Sheet is assessed in terms of material and media. Here are the results:

\begin{tabular}{|c|c|c|c|c|}
\hline \multirow{2}{*}{ Num } & Aspect & \multicolumn{2}{|c|}{ Validator } & \multirow{2}{*}{$\overline{\mathbf{x}}$} \\
\cline { 3 - 4 } & Interesting material & $\mathbf{1}$ & $\mathbf{2}$ & 4 \\
\hline 1 & The material is in core competencies and \\
basic competencies & 4 & 4 & 3 \\
\hline 3 & Relationship with the concept of everyday \\
& life & 3 & 3 & 3 \\
\hline 4 & Interesting and challenging observation \\
activities & Sentence is clear & 3 & 3 & 3,55 \\
\hline 5 & Simple sentence & 3 & 3 & 3 \\
\hline 6 & Language is easy to understand & 3 & 3 & 3,5 \\
\hline 8 & Color selection is appropriate and attractive & 4 & 4 & 4 \\
\hline 9 & Facilitate observation & 4 & 4 & 4 \\
\hline
\end{tabular}


ISSN No:-2456-2165

\begin{tabular}{|c|c|c|c|c|}
\hline \multirow{2}{*}{ Num } & \multirow{2}{*}{ Aspect } & \multicolumn{2}{|c|}{ Validator } & \multicolumn{2}{|c|}{$\overline{\mathbf{x}}$} \\
\cline { 3 - 5 } & Motivate students to learn & 4 & 4 & 4 \\
\hline 10 & Percentage & & & $\frac{3,55}{4} \times 100 \%=88.75 \%$ \\
\hline
\end{tabular}

Table 7:- Validation of Student Material Expert Activity Sheets

The table above shows the average score of validation of Student Activity Sheets from material experts is 3.55 with a valid category.

\begin{tabular}{|c|c|c|c|c|c|}
\hline \multirow{2}{*}{ Num } & \multirow{2}{*}{ Rated aspect } & \multicolumn{2}{|c|}{ Validator } & \multirow{2}{*}{$\overline{\mathbf{x}}$} & \multirow{2}{*}{$\overline{\mathbf{x}}$ total } \\
\hline & & 1 & 2 & & \\
\hline 1 & Font size and type accordingly & 4 & 4 & 4 & \multirow{20}{*}{3,83} \\
\hline 2 & The writing is clear and easy to read & 4 & 4 & 4 & \\
\hline 3 & Harmony of text with images & 4 & 4 & 4 & \\
\hline 4 & Effective picture & 3 & 3 & 3 & \\
\hline 5 & Interesting picture & 4 & 4 & 4 & \\
\hline 6 & The picture for the experiment is clear & 4 & 4 & 4 & \\
\hline 7 & $\begin{array}{l}\text { The combination of writing and images can } \\
\text { convey a message }\end{array}$ & 4 & 4 & 4 & \\
\hline 8 & $\begin{array}{l}\text { The combination of images with balanced } \\
\text { writing }\end{array}$ & 4 & 4 & 4 & \\
\hline 9 & Manufacturing materials are easy to obtain & 4 & 4 & 4 & \\
\hline 10 & Appropriate for Primary Schools & 4 & 4 & 4 & \\
\hline 11 & Size according to standard & 4 & 4 & 4 & \\
\hline 12 & Interesting cover & 3 & 4 & 3,5 & \\
\hline 13 & Appearance of attractive contents & 4 & 4 & 4 & \\
\hline 14 & Print quality & 4 & 4 & 4 & \\
\hline 15 & Can be carried easily & 4 & 4 & 4 & \\
\hline 16 & Interesting for students & 4 & 4 & 4 & \\
\hline 17 & grow motivation & 3 & 3 & 3 & \\
\hline 18 & The right color choice & 4 & 4 & 4 & \\
\hline 19 & $\begin{array}{l}\text { Shapes and lines are attractive, simple, and } \\
\text { helpful in understanding concepts }\end{array}$ & 3 & 3 & 3 & \\
\hline \multirow[t]{2}{*}{20} & Balanced system & 4 & 4 & 4 & \\
\hline & Percentage & & & $\begin{array}{l}\frac{3,83}{4} \times 100 \% \\
=95,75 \%\end{array}$ & \\
\hline
\end{tabular}

Table 8:- Validation of Media Student Activity Sheets

The table above shows the average score of validation of Student Activity Sheets from material experts is 3.55 with a valid category

From the two tables above we can know that the average feasibility of Student Activity Sheets developed is the average score of both aspects, namely 3.69 (92.25\%) with very good criteria. It shows that the Student Activity Sheet developed is very feasible.

\section{B. Practicality of Student Activity Sheets}

Practicality Student activity sheets can be seen from student activities during three meetings. Here are the data: 
ISSN No:-2456-2165

\begin{tabular}{|c|c|c|c|c|c|}
\hline \multirow{2}{*}{ Num } & \multirow{2}{*}{ Aspect } & \multicolumn{4}{|c|}{ Assessment } \\
\hline & & 1 & 2 & 3 & $\overline{\mathbf{x}}$ \\
\hline 1 & Listen to the explanation & 4 & 4 & 4 & 4 \\
\hline 2 & Reading teaching material & 4 & 4 & 4 & 4 \\
\hline 3 & Doing task & 3 & 4 & 4 & 3,67 \\
\hline 4 & Make observations & 4 & 4 & 4 & 4 \\
\hline 5 & Collaborate between groups & 4 & 4 & 4 & 4 \\
\hline 6 & Communicating the results of group work & 3 & 3 & 4 & 3,33 \\
\hline 7 & Ask questions, express opinions & 3 & 3 & 3 & 3 \\
\hline \multirow[t]{6}{*}{8} & Behavior is appropriate or relevant & 3 & 4 & 4 & 3,67 \\
\hline & Total score & 28 & 30 & 31 & 29,67 \\
\hline & Percentage & $87,5 \%$ & $93,75 \%$ & $96,87 \%$ & \\
\hline & Average score & \multicolumn{4}{|c|}{$\frac{29,67}{8}=3,71$} \\
\hline & Reliability & \multicolumn{4}{|c|}{$\frac{29,67}{32} \times 100 \%=92,71 \%$} \\
\hline & Category & \multicolumn{4}{|c|}{ Very good } \\
\hline
\end{tabular}

Table 9: Student Activity

The table above shows the practicality of the Student Activity Sheet achieving a score of 3.71 in the excellent category. It shows that the Student Activity Sheet is very practical to use.

\section{Effectiveness of Student Activity Sheets}

The effectiveness of Student Activity Sheets can be seen from the Student Response Questionnaire and the results of the pre-test. Here are the data:

\begin{tabular}{|c|c|c|c|c|}
\hline \multirow{2}{*}{ Student } & \multicolumn{2}{|c|}{ Score } & \multirow{2}{*}{ N-Gain } & \multirow{2}{*}{ Criteria } \\
\cline { 2 - 5 } & Pretest & Posttest & & \\
\hline 1 & 50 & 100 & 1 & High \\
\hline 2 & 63 & 100 & 1 & High \\
\hline 3 & 50 & 97 & 0.94 & High \\
\hline 4 & 63 & 87 & 0.65 & Sufficient \\
\hline 5 & 65 & 90 & 0.71 & High \\
\hline 6 & 55 & 87 & 0.71 & High \\
\hline 7 & 50 & 82 & 0.64 & Sufficient \\
\hline 8 & 68 & 100 & 1 & High \\
\hline 9 & 65 & 82 & 0.49 & Sufficient \\
\hline 10 & 50 & 75 & 0.5 & Sufficient \\
\hline 11 & 50 & 82 & 0.64 & Sufficient \\
\hline 12 & 63 & 75 & 0.32 & Sufficient \\
\hline 13 & 50 & 90 & 0.8 & High \\
\hline 14 & 65 & 100 & 1 & High \\
\hline 15 & 78 & 95 & 0.17 & Low \\
\hline 16 & 58 & 100 & 1 & High \\
\hline 17 & 55 & 100 & 1 & High \\
\hline 18 & 50 & 85 & 0.71 & High \\
\hline 19 & 78 & 95 & 0.81 & High \\
\hline 20 & 50 & 97 & 0.94 & High \\
\hline Average & $\mathbf{5 8 . 1 5}$ & $\mathbf{8 9 . 9 5}$ & $\mathbf{0 . 7 5 1}$ & High \\
\hline & 156 & $P r$ & & \\
\hline
\end{tabular}

Table 10: Pretest and posttest results
The table above shows N-Gain 0.751. N-gain above 0.70 indicates high $\mathrm{N}$-gain. This shows that there is an increase in critical thinking skills.

Increasing student pretest and posttest scores can be seen from the following graph!

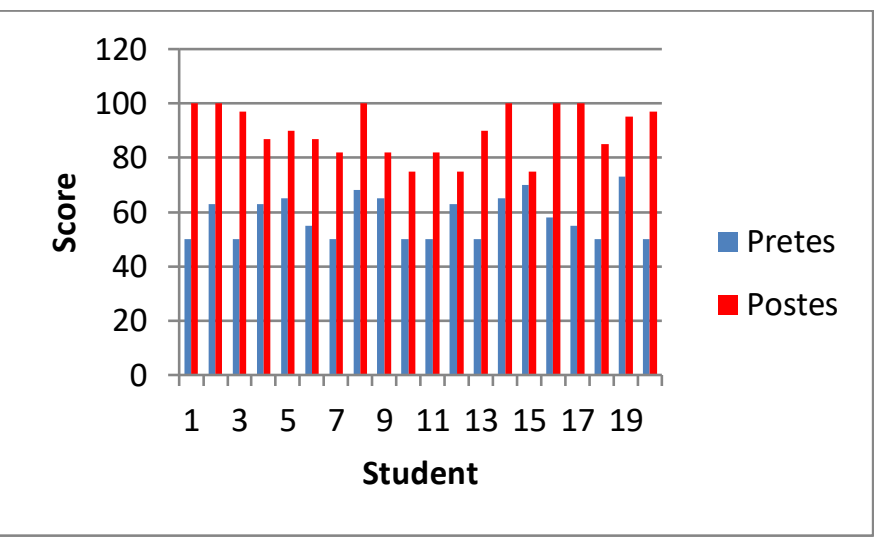

Chart 1:- Student pretest and posttest results

The graph above shows an increase in the pretest and posttest of critical thinking skills.

The following are the results of student responses using Student Activity Sheet based Surabaya batik local wisdom : 


\begin{tabular}{|c|c|c|c|}
\hline \multirow{2}{*}{ Num } & \multirow{2}{*}{ Statement } & \multicolumn{2}{|c|}{ The response } \\
\hline & & Yes & No \\
\hline 1 & Students feel happy & 80 & 0 \\
\hline 2 & Shiva feels interested & 64 & 16 \\
\hline 3 & Attractive appearance & 72 & 8 \\
\hline 4 & Easy to understand & 64 & 16 \\
\hline 5 & The color is interesting & 64 & 16 \\
\hline 6 & Letters clearly read & 56 & 24 \\
\hline 7 & Material is easy to understand & 72 & 8 \\
\hline 8 & Interest in learning increases & 80 & 0 \\
\hline 9 & Easy to do evaluation questions & 64 & 16 \\
\hline 10 & $\begin{array}{c}\text { Interested in participating in } \\
\text { learning using the Student } \\
\text { Activity Sheet }\end{array}$ & 80 & 0 \\
\hline & $\Sigma$ & 696 & 104 \\
\hline & Percentage & $87 \%$ & $13 \%$ \\
\hline
\end{tabular}

Table 11: Student Response

\section{CONCLUSION}

Based on data analysis and discussion, it can be concluded that the Student Activity Sheet based local wisdom that has been developed is declared feasible, practical, and effective in use. Feasibility of Student Activity Sheet based Surabaya batik local wisdom was declared feasible with a validation percentage of $88.75 \%$. Practicality in learning is evidenced by the results of teacher activity of $96.4 \%$ and student activities of $92.71 \%$. The effectiveness in improving student learning outcomes is shown by $\mathrm{N}$-Gain 0.751 which shows high $\mathrm{N}-$ Gain. The score shows an increase in critical thinking skills using the Student Activity Sheet based Surabaya Batik local wisdom in the high category.

\section{REFERENCES}

[1]. Agung, Leo. 2015. The Development of Local Wisdom-Based Social Science Learning Model with Bengawan Solo as the Learning Source. American International Journal of Social Science Vol. 4, No. 4; August 2015 ISSN 2325-4149 (Print), 2325-4165 (Online) (C) Center for Promoting Ideas, USA

[2]. Akbar, S. 2013. Instrumen Perangkat Pembelajaran. Bandung: Remaja Rosdakarya. Bandung

[3]. Ali Ridwan, Nurma. 2007. Landasan Keilmuan Kearifan Lokal. STAIN Purwokerto.

[4]. Andi Prastowo. 2011. Panduan Kreatif Membuat Bahan Ajar Inovatif. Yogyakarta: Diva Press

[5]. Arikunto, Suharsimi. 2008. Prosedur Penelitian Suatu Pendekatan Praktek. Jakarta: Rineka Cipta

[6]. Birgili, B. 2015. Creative and Critical Thinking Skills in Problem-based Learning Environments. Journal of Gifted Education and Creativity, 2(2), 71-80.

[7]. Carin, A.A. \& Sund, R.B. 1989. Teaching Science Through Discovery. Columbus: Merrill Publishing Company.

[8]. Dwi Lestari, Suerna. 2012. Mengenal Aneka Batik. PT Balai Pustaka: Jakarta

[9]. Fisher, A. 2009. Berpikir Kritis Sebuah Pengantar. Jakarta: Erlangga
[10]. Gasong, Dina. 2018. Belajar dan Pembelajaran. Yogyakarta: CV. Budi Utama

[11]. Gunawan, A. W. 2003. Genius Learning Strategy Petunjuk Praktis untuk Menerapkan Accelarated Learning. Jakarta : Gramedia Pustaka Utama.

[12]. Hake, R, R. (1999).Analyzing Change/Gain Scores.AREA-D American Education Research Association's Devision.D, Measurement and Reasearch Methodology.

[13]. Marfai, Aris, M. (2012). Pengantar Etika Lingkungan dan Kearifan Lokal. Yogyakarta: Gadjah Mada University Press.

[14]. Meltzer, E.David. "The relationship between mathematics preparation and conceptual learning gains in physics : A possible :hidden variable in diagnostic pretest score". Ammerican Association of Physics Teachers : American Journal Physics; 2002 , 70 ( (2), 1259-1268, $1260 \mathrm{p}$.

[15]. Norris, S. and Ennis, R. 1989. Evaluating Critical Thinking. Pacific Grove, CA: Critical Thinking Press and Software.

[16]. Prastowo, Andi. 2012. Panduan Kreatif Membuat ahan Ajar Inovatif. Jogjakarta: DIVA Press.

[17]. Ratumanan, T. G., dan Laurens, T. (2011). Penilaian Hasil Belajar Pada Tingkat Satuan Pendidikan. Surabaya: Unesa University Press.

[18]. Saeed, S. J. dan Rousta, S.N. (2013). "The Effect of Problem-based Learning on Critical Thinking Ability of Iranian EFL Students". Journal of Academic and Applied Studies, Vol 3 (7), hlm. 1-14

[19]. Sugiyono. 2012. Metode Penelitian Kuantitatif, Kualitatif, dan R \& D. Bandung: Alfabeta.

[20]. Susanto, Ahmad. 2013. Teori Belajar dan Pembelajaran di Sekolah Dasar. Jakarta: Kencana Prenadamedia Group

[21]. Trefil, James and Robert M.Hazen. 2000. The Science: an Integrated Approach. Canada: John Willey \& Sons, Inc.

[22]. Trianto. 2010. Model Pembelajaran Terpadu. Jakarta: Bumi Aksara. 